\title{
The Pre-parliamentary Phase in Lawmaking: The Power Issues at Stake
}

\author{
Christine Guy-Ecabert
}

\subsection{INTRODUCTION}

Swiss law contains a certain number of rules concerning the lawmaking process. In this framework, the federal administration has developed an impressive practice in lawmaking which has been progressively established in specific guides and enshrined in law. The aim of this chapter will not be to present all the lawmaking, but will instead focus on the pre-parliamentary phase during which the federal administration has to act.

Before coming into force, a federal law goes through four phases: preparliamentary, parliamentary, referendum, and implementation. Swiss are generally quite familiar with the parliamentary phase of the legislative process; debates in the two chambers of the Federal Assembly are well covered by the media during each of its four annual sessions. By contrast, the pre-parliamentary phase remains relatively unknown if not confidential (Sciarini 2011). Yet it is during this phase that the draft legislation submitted to parliament is negotiated, and this partly determines its future fate. The federal administration plays a major role in this phase, which is why it is worth devoting attention to this preparatory phase when addressing

\section{Guy-Ecabert $(\bowtie)$}

Faculty of Law, University of Neuchâtel, Neuchâtel, Switzerland e-mail: christine.guy-ecabert@unine.ch

(C) The Author(s) 2019

A. Ladner et al. (eds.), Swiss Public Administration, Governance and Public Management, https://doi.org/10.1007/978-3-319-92381-9_5 
public administration and the lawmaking process at the federal level. To make it more explicit, the dossier on the revision of the Federal Data Protection Act (DPA) will be used to illustrate the room for maneuver available to the federal administration, and more specifically to the federal offices. $^{1}$

Chronological logic is used first to describe the preparatory phase, which focuses more on the process than on organizational issues. Next, we present the supporting material (reference documents) that governs this process, and discuss the limits of their accessibility. Then we contrast how the federal authorities portray the objectives of the pre-parliamentary phase with the results of studies by legal scholars and political scientists. Finally, we examine an underlying issue, namely what is at stake in terms of power in the pre-parliamentary process.

\subsection{The Stages of the Pre-Parlamentary Process}

In federal law, there are several categories of legal instruments. The major ones are laws and ordinances; only the first are considered, as they have to be adopted by the legislature. Moreover, in Switzerland, laws (Art. 164 Federal Constitution, abbrev. as Const.) can be subjected to an optional referendum (Art. 141 Const.). In terms of competencies, because it involves preparing a legislative act at the level of law, it is the responsibility of the Federal Council, the national executive (Art. 181 Const.), to direct the pre-parliamentary phase. This is different if the impulse for the law comes from a parliamentary or cantonal initiative, a rare situation-less than 20\%-that will not be considered here (Art. 181 and 171 Const.; Art. 7 Government and Administration Organisation Act (GAOA); Federal Office of Justice 2014: 100).

We draw here on the many federal guidelines which govern the preparliamentary process (for a particularly critical stance, see Jochum and Ledermann 2009: 92), and follow the chronological development: the design of the legislative project (Sect. 5.2.1), the preliminary draft and its explanatory report (Sect. 5.2.2), and the external consultation on the preliminary draft and finalizing the bill (Sect. 5.2.3).

\footnotetext{
${ }^{1}$ The author would like to thank Simone Füzesséry, deputy head of the Legislation Projects and Methodology Unit, Public Law Division, Federal Office of Justice and co-responsible for the revision of the Federal Law on Data Protection, for answering numerous questions as well as his careful reading of the present text.
} 


\subsubsection{Designing the Legislative Project}

It is at the beginning of the first, conceptualizing, phase that the necessary information for analyzing the problem is collected and a project organization is set up. The scope of knowledge needed depends on the structure of the project, understood as the organization of the project. The choices here are, on the one hand, a function of the staff resources and expertise of the office in charge, and on the other hand, the likelihood of finding a sufficient consensus. In other words, the more complex and politically sensitive the problem is, the larger the group that prepares the project.

Overall, three variants are possible. The first is an internal working group, which presupposes the federal administration has the necessary knowledge. The second is a joint working group, in particular, committees composed equally of federal and cantonal representatives, formed when the latter are particularly concerned. The third, in exceptional cases when specialist expertise seems needed, is a group of experts from outside the administration. The most common is the joint working group, which brings together interdisciplinary skills. Nevertheless, lawyers are very evident in these different types of working groups.

The conceptual phase allows for the construction of a base of knowledge on which the draft law and the explanatory report-called the 'message fédéral'-later rest. It is based on a material lawmaking approach whose goal is to improve the ability of the law to act on social reality (Flückiger 2008). One can see this as a problem-solving cycle with three stages: defining the problem (by analyzing its causes and its dynamic), determining the objectives (describing the desired future state by prioritizing the objectives to be achieved), and deciding on the instruments to use (presenting the variants in conjunction with the various instruments of action available to the government, and roughly assessing them before selecting which to use) (Jochum and Ledermann 2009). Depending on the circumstances, this iterative approach can be repeated at each state of the pre-parliamentary process.

The problem-solving cycle culminates in drafting an outline of a normative act which summarizes - in the form of theses or guiding principles - the material lawmaking approach, without yet expressing it in the form of a normative text. The following sketch also provides variants to the chosen solution (Art. 141 of the Law on Parliament). It is during the conceptualizing phase that the federal administration can best develop its room for maneuver or be at its most creative. 
The DPA case: Almost 20 years after it came into force (on 19 June 1992), it was clear that the Swiss data protection law was outdated, superseded by technological and societal developments and the new requirements under European law. Based on an evaluation carried out by an interdisciplinary research group (Büro Vatter 2011), the Federal Council instructed the Federal Department of Justice and Police to revise the law (Federal Council 2011). The Federal Office of Justice, which was responsible for this dossier, established a working group composed of representatives from the federal administration, the cantons, the universities, as well as from consumer protection and economic interest groups. They drew up a report - incorrectly entitled 'Outline of a Normative Act' - which described the basic axes of the revision, the form of the normative act, the general regulatory structure, its normative density, and a timetable for implementation (Federal Office of Justice 2014). In fact, no outline will ever be drafted, despite the directive calling for it by the Federal Office of Justice, probably in order to avoid consulting the head of the department again. Instead, the Swiss Institute of Comparative Law was asked to provide expert reports on how data protection is organized in various countries (Germany, France, Italy, the Netherlands, Poland, Sweden, the UK, Finland, Slovenia, Spain, and in Argentina, Japan, New Zealand, Singapore, South Korea, and the U.S.) and what powers data protection authorities have in these countries. Contracts were also given to the Universities of Applied Sciences in Zurich and Lucerne to analyze the jurisprudence and literature on the cost-benefit ratio in the area of data protection.

\subsubsection{Preparing the Preliminary Draft and the Explanatory Report}

The outline of a normative act, which summarizes the main political and legal features of the proposed bill, is now transformed into a text, the draft bill. This is where formal legal rules, in particular those governing structuring, are crucial. The original drafting language is most often German, with a parallel French translation. Depending on the available resources, the text is drafted in parallel in two official languages but often in just one. Italian is the poor relation in the federal administration and is generally only a language of translation rather than of formulation.

The DPA case: The working group was composed largely of French-speakers, so the draft data protection law was formulated originally in French and then immediately translated into German. This is exceptional. 
Once the draft is prepared, its potential effects are evaluated. According to the letter of the law, this includes speculation about 'the consequences the project, if carried out, will have on the finances and the status of the personnel of the Confederation, the cantons and the communities, the modalities proposed and their financing, the impact it has had or will have on financial planning, and the cost/utility evaluation of the proposed measures'; 'the economic, social and environmental consequences of the proposed project and its effects on future generations'; and the foreseeable 'consequences the project will have on equality between men and women' (Art. 141 (2)(f, g, and i), Federal Act on the Federal Assembly). However, the Confederation limits this type of study, called a Regulatory Impact Analysis (RIA), to an economic analysis (Federal Department of Economic Affairs 2013). In undertaking these prospective evaluations, the administration seeks to improve the preliminary draft and the explanatory report which comments on it.

The DPA case: After having read the 'outline of a normative act', the Federal Council instructed the Federal Department of Justice and Police to formulate a draft law together with three other Departments, and together with the Federal Data Protection and Information Commissioner.

On behalf of the Federal Office of Justice and of the State Secretariat for Economic Affairs, a private firm conducted an RIA (PWC 2016). According to its conclusions, it is necessary to legislate, in particular due to the evolution of law at international and European levels. The RIA also showed that from the point of view of firms operating in Switzerland, the preliminary draft would significantly affect those companies with medium or high exposure to data protection law. With respect to international competition, companies would nevertheless benefit from Switzerland maintaining its status as a country with an adequate level of data protection. Those concerned would benefit from a strengthening of their position.

The first part of the explanatory report of 21 December 2016 on the preliminary draft federal law (on the total revision of the data protection law and on the modification of other federal laws) places it in its national and international contexts, discusses the objectives of the revision (adapting Swiss legislation to technological developments and integrating changes in European regulations), provides a comparative study of relevant laws, and addresses implementation issues. Another section addressed the new standards, commenting on them article by article. Finally, the various financial, economic and social consequences on the IT sector are evaluated. The report also addresses various legal issues, in particular the constitutionality of the preliminary draft in terms of case law, compatibility with international agreements, and the form of the draft act. 


\subsubsection{Consulting About the Preliminary Draft and Finalizing the Bill}

The consultation process marks the beginning of opening up the preparliamentary process. The addressees are organizations which do not belong to the federal administration. Federal judicial authorities are only consulted on projects which affect their own processes or organization (Art. 11, Federal Ordinance on the Consultation Procedure). The cantons, the political parties, local authorities' associations (cities and communities), and those circles interested in drafting federal laws are also involved in the consultation, one which is supposed to take into consideration all the interests at stake. This is a key instrument of cooperative federalism (Federal Council 2004) which allows NGOs to contribute to the formation of public opinion and help establish whether a project of the Confederation is 'materially correct, executable and likely to be accepted' (Art. 2 (2), Federal Ordinance on the Consultation Procedure).

The drafts of federal laws are generally open to consultation, though the federal administration can waive this (Art. 3a, Federal Act on the Consultation Procedure). This takes place in principle over a period of three months. The federal administration drafts the final report, which presents and weighs the expressed opinions. If the Federal Council approves the bill and the preliminary report, it is sent to the Federal Assembly. This marks the end of the pre-parliamentary phase and the beginning of the parliamentary process.

The DPA case: As part of the consultation process, which lasted a little over three months from the end of December 2016 to the beginning of April 2017, the Federal Department of Justice and Police invited 65 organizations - in particular the federal courts, the cantons, the political parties and various interested organizations - to give their opinions about this proposed bill, while 164 other actors, unasked, also provided input. The Department received 222 statements, 176 from relevant circles (Federal Office of Justice 2017: 5). On 10 August 2017, the Federal Office of Justice published a 79-page summary of the results of the consultation process, laying out the main points (an assessment of the need to legislate and a general assessment of the preliminary draft), along with details on the opinions about specific articles. On September 15, 2017, the Federal Council received the 247-page report about a federal law to revise the federal data protection act (as well as about modifying other federal laws), along with a draft bill which contained 67 articles (Federal Council 2017: $6565)$. 


\subsection{Reference Documents and Their Accessibility}

Being familiar with a process internal to the administration implies having access not just to the legal instruments that define it abstractly, but also to the files of the preliminary legislative procedures which are in process or are completed. The few normative texts can be found in the classified compilation of Swiss law. Anyone who wants to obtain information on the preparliamentary process can readily find the many texts meant to guide the administration in its work-constitutional norms, laws, ordinances, and directives - on the webpages of the federal administration. On the one hand, the documents concern the phase which has external effects, meaning the consultation process (Art. 147 Const., Federal Act and Federal Ordinance on the Consultation Procedure), and on the other hand, they are related to information provided to the Federal Assembly by the Federal Council which defines the content of the explanatory report, which the second addresses to the first (Art. 141 Federal Act on the Federal Assembly).

The Swiss Confederation did not enact a 'law of laws' forcing a legislator to follow a methodical approach in drafting legislation (Flückiger 2008). However, numerous directives guiding the administration can be found on the respective websites. Thus, the Guide de législation (Federal Office of Justice 2007) and the three modules (law, regulations, and parliamentary initiative) which complement it as well as the Directive sur la présentation d'esquisses d'acte normatif may be found on the website of the Federal Office of Justice. The Directives sur la technique législative and the Aide-mémoire sur la présentation des messages du Conseil fédéral are available on that of the Federal Chancellery. These texts provide step-by-step guides for the administrators responsible for carrying out the internal procedures. There is thus a mass of information, the largest part of which comes from the good practices of the federal administration. The practice of consultation, for example, is an old tradition which was codified by a Federal Council directive on May 6, 1970, about the preliminary process for legislation (Federal Council 1970: 1003). This was reinforced by a Federal Council order on June 17, 1991; the Law on the Consultation Procedure was only first passed in 2005.

Documents about each draft bill in the pre-parliamentary phase are as readily accessible for the procedures in progress, though only once the external consultation has begun. Electronic records are more or less wellorganized; they are provided as a function of the care various offices give to their own webpages. 
The DPA case: The 'strengthening data' file of the Federal Office of Justice is particularly well-documented. One finds in it a summary of the political and legal motivations for revising the law and of the preliminary steps taken, the reports from the experts, the documents made available for consultation, the positions taken and the results of the consultation, along with the preliminary report and the bill.

It would be fascinating to add information to this layer of legal and technical information, about what is at stake, in terms of power, at the heart of government. However, Federal Council deliberations are not public (Art. 21, GAOA), nor are the documents it produces. Indeed, despite a Copernican revolution-which has made it a priority to have transparency outweigh secrecy in the access to federal government documents - the Federal Council does not fall under the scope of this law. In the case of documents relating to co-reporting procedures-the final stage of negotiations between the heads of departments which precedes the Federal Council's decision-they too evade the principle of transparency (Art 8 (1-4) Freedom of Information Act).

The reason for this is that a collegial authority must be able to remain silent about how it reaches its opinions and makes its decisions in order to present a united front to the public. The public is deprived of knowledge about the clash of ideas, the political conflicts, and the alliances formed within the executive-certainly for good political reasons-and does not know what the real power issues are that are at stake. It is thus doubtful that the Federal Council might one day risk opening the door of its 'federal chalet'" to allow a [Bruno] Latour interested in the Swiss political system to research and publish a work entitled 'The Making of Swiss Law: An ethnography of the Federal Council'. ${ }^{3}$ As for the negotiations which take place in the offices and in the working groups in which preliminary drafts and legal projects are conceived, they remain secret. They thus evade the rules of the democratic game which is played during parliamentary debates.

\footnotetext{
${ }^{2}$ Owing to its decor and furnishings, the room in which the Federal Council meets is given this amused moniker (https://www.admin.ch/gov/fr/accueil/conseil-federal/ou-travaillele-gouvernement/salle-seance-conseil-federal.html).

${ }^{3}$ See the remarkable work by Bruno Latour (2002), especially the chapter 'Quel étrange atelier d'écriture': 69 et seq.
} 


\subsection{The Objectives of the Pre-Parliamentary Process}

The political organs of the Confederation are in agreement over the two objectives of the pre-parliamentary process. On the one hand, it is meant to contribute to the quality of the law (Sect. 5.4.1); on the other, it is meant to encourage political acceptability in the parliamentary phase and subsequently in the referendum phase (Sect. 5.4.2). After briefly describing the means the authorities put into practice to achieve these objectives, we contrast them with critical studies written by legal scholars and political scientists (Sect. 5.4.3).

\subsubsection{To Contribute to the Quality of the Law}

The quality of the law can be judged from a legal, editorial, or political vantage point, and it is a topic which always ignites controversy (Flückiger and Guy-Ecabert 2015: 21-45). It is possible to improve the legal quality of the law before it is adopted or published (as a preventive control) or after its publication or its entry into force (as a subsequent control, see the chapter by Mahon). Switzerland does not have the judicial review of federal laws once they are passed, and even if they are unconstitutional, the Federal Supreme Court and the other authorities are obliged to apply them (Art. 190 Const.).

As early as the preliminary phase, the Federal Office of Justice is primarily responsible for monitoring whether draft federal laws conform with higher law (constitutional provisions), whether they are compatible with international law, and whether they are basically accurate. Its Legislation I and II Units and its European Law and Schengen Coordination Unit provide this legislative support. It is not uncommon for a draft bill to be checked six or eight times by the Federal Office of Justice (Mader 2006: 5 ), and by virtue of this, this office enjoys considerable de facto autonomy (Mader 2006: 7).

Other offices and administrative units come into play when questions relevant to their area of expertise arise. For example, the Federal Chancellery's legal department systematically examines proposed legislative acts from the perspective of legislative technique and the drafting of laws (Art. 7 (3) Federal Ordinance on the Organization of the Federal Department of Justice and Police and Art. 4 (1) (b) Federal Ordinance on the Organization of the Federal Chancellery). As needed, the Federal 
Finance Administration checks compliance with budget law and the law on subsidies, the Directorate of International Law checks compatibility with Switzerland's international obligations, the Directorate for European Affairs of the Federal Department of Foreign Affairs monitors compliance with the agreements concluded between Switzerland and the EU, and the Federal Data Protection and Information Commissioner is concerned with data protection. The opinions provided by the Federal Office of Justice and other administrative bodies are certainly not binding. Nevertheless, given the subject matter, if the competent offices do not take up the conclusions reached by the Federal Office of Justice, they must explain why.

Evaluating the quality of the law comparatively would require research into many legal systems, most likely the reason why such studies have yet to be undertaken. It would also be necessary to decide first on a definition of the 'the quality of the law' and establish some means for correlating this 'quality' with the pre-parliamentary process. Nevertheless, some authors cautiously estimate that federal law is 'rather affordable, concise and understandable in international comparison' (Müller and Uhlmann 2013: 49; Flückiger and Guy-Ecabert 2008: 40; Flückiger 2008: 32).

\subsubsection{To Successively Build a Consensus}

In Switzerland, laws passed by the Federal Assembly are vulnerable as they can be subjected to (an optional) popular referendum. The consequence of this Damoclean sword is that the entire pre-parliamentary process is designed and organized so as to progressively build a consensus - in the hope of escaping the threat of a subsequent referendum. This intent is clearly expressed by the Federal Council: 'the question whether a project will be accepted politically is extremely important for legislators in light of the possibilities the referendum provides within the Swiss democratic system' (Federal Council 2004: 498). The search for consensus commences already in the very first stage, the conceptualizing one, of the pre-parliamentary phase when the experts who will work together in the mixed working groups are selected. Consensus is also sought through the joint interdepartmental report intended for the Federal Council: the intent is to iron out the differences between the departments beforehand (Müller and Uhlmann 2013: 148). This consensus-building is also particularly evident during the process of consulting outside interested parties. 
This idea of building consensus is not without its psycho-sociological foundation. It is based on the assumption that involving actors in a decision means that, having accepted that they will participate and contribute to a decision, they will also support it later. However, many political science studies show the opposite to be true (Sciarini 2015: 31; 2011: 196). Both in the parliamentary and referendum phases, media coverage of concertation or consultation efforts compels actors to reveal their positions publicly. Positions stated clearly and openly can exacerbate conflicts. Contrary to what might be expected in a good theory of negotiation, consultation may well not encourage an open exchange of opinions and can hinder symmetrical interactions, leading to an escalation of conflict (Papadopoulos 1997: 48). The ability of the actors to negotiate and find compromise can thus be affected by media coverage of the preparliamentary procedure.

\subsubsection{Critics}

The consultation process has its critics. It has the potential of strengthening conservative views by allowing those who reject change to oppose it, leading to solutions close to the status quo. It can also lead to selfcensorship on the part of the authorities (Papadopoulos 1997: 47), and even worse, to a large deficit in Swiss innovation policy (Keller 1997: 14).

The DPA case: The EU imposes very severe criminal sanctions for violations of data protection. To be in compliance, the preliminary draft sanctioned various infractions by imposing a maximum fine of 500,000 CHF. Following the consultation process, the draft law halved this amount, though at the risk that the EU could declare the DPA to be insufficiently deterrent.

One criticism is that consultation considerably lengthens the decisionmaking process. Legislative proceedings last, on average, for 51 months (more than four years), of which just over two-thirds are taken up by the pre-parliamentary process, or a little under three years (Federal Office of Justice 2007: 23).

Despite these critiques, the stakeholders involved in the consultation process are of the opinion that it allows factual elements to be brought in which both improve the draft law and help right the power imbalances between the actors concerned. It also contributes to greater transparency in the decision-making process (Christe et al. 2016: 212). In the end, it 
also helps counter the centrifugal forces which exist in a multicultural society, and thus helps preserve social cohesion (Papadopoulos 1997: 46).

\subsection{Decrypting the Power Issues}

We now focus on the question of who has decision-making power, in a material sense, within the domestic legislative process. It can be considered from two perspectives. First, it concerns the relations between the executive - the Federal Council-and the different levels of the federal administration (head of department, offices and general secretariats). Second, it is about the designation of the leading office of a given project.

The Federal Council functions according to two principles: collegiality (all its members collectively assume responsibility for governing), and the departmental principle (each member heads one or more departments) (Auer et al. 2013: 54). In this configuration, the federal administration, hierarchically subordinated to the Federal Council, is not considered as an organ of the state.

As the chronological presentation of the process highlighted, such an organization has an impact on the power game that is played. The executive, meaning the government relying on a public administration is subdivided into offices and agencies, reigns supreme over the first phase of the legislative process. It is here that the major legal and political decisions about a given project are taken. These decisions will only later be submitted, in the form of a bill, to the Parliament. As we have focused here only on the preliminary phase, we must leave aside the very important question of the horizontal balance of power between government and parliament throughout the legislative process (Sciarini 2015). The question which concerns us here is the vertical distribution of power between Federal Council, the departments, the offices of the federal administration, and the general secretariats of the departments. We will approach this from the top down.

In the context of implementing federalism, where the federal executive is transferring the power to implement federal law to the cantons, the 'prelegislative' phase is important from the point of view of political power. Nonetheless, this power is largely delegated to the federal administration. Though the Federal Council certainly has the right to make decisions, which it makes use of at each stage of the pre-parliamentary process, it in fact exercises its power in the form of a right of veto over the decisions 
made by the federal administrative offices rather than making collegial decisions within the Council. Indeed, everything is played out, in a formalized decision-making process, called the interdepartmental co-report procedure, prior to the Federal Council meeting, which is to say in the meeting of the department heads to prepare a joint interdepartmental report (Art. 15 GAOA and Art. 5 Ordonnance on Government and Administration Organization; Müller and Uhlmann 2013: n. 147-150).

The first step is consultation at the level of the federal offices inside the departments. This makes it possible to gather proposals and amendments, and establish whether the relevant office will accede or resist. In a second step, the dossier goes back to the heads of other departments. They can express their disagreement in a report addressed to the head of the responsible department, who can in turn take a position in response to it and to the reports submitted by other departments. A last round of replies from the departments to this response is also possible. These reports, signed by the heads of departments, are in fact prepared by the federal offices (Mader 2001: n. 45), and are the veritable 'backbone' of the federal administration (Grisel 1984: 213); they play a major role in the decision of the Federal Council. ${ }^{4}$ Unlike the Federal Councilors, the heads of federal offices, managers of domains, or heads of units (Mader 2006) are not subject to re-election. Because they define the principal orientations, they exercise major and lasting influence over the procedure and the bills.

The general secretariats of the departments are also a locus of power. Serving as general staff, they assist the heads of departments in performing various tasks (Art. 143 et seq. GAOA). However, they benefit from having a different position. They are certainly closer to the head of the department than to the heads of the offices and can intervene at the highest level, at the end of the process. On the other hand, they no longer influence the important points which have not previously been considered in the federal offices internally.

At the very beginning of the preliminary procedure, the new legislative project is assigned to one federal office. Although this decision falls within the material competence of the Federal Council, it is not the result of a political negotiation, on a case-by-case basis, between the Councilors. It is based instead on regulations it has enacted about how the seven federal

${ }^{4}$ As Alain Berset confirmed when he exclaimed: 'Heavens - parliament has dismantled my proposed law!' Cited in Flueckiger and Guy-Ecabert (2008: 141-142). The author, now a Federal Councilor, was vice-president of the Council of States at the time. 
departments are (to be) organized, establishing such distribution according to subject (e.g., based on the areas of expertise of the various offices). These offices are supposed to organize themselves in such a way that they can assume their respective legislative responsibility.

In fact, they have very different human resources available to produce quality legal texts. Some, such as the Federal Office of Public Health or the Federal Office for the Environment, have legal services with many employees, or even quality assurance systems. Others, by contrast, do not even have positions for lawyers. In such cases, lawyers from the Federal Office of Justice or the Federal Chancellery provide assistance. In this context, the internal legislative process begins in decentralized 'workshops' which bring together various skills and resources. In a Weberian sense, the administrative system 'delineates spheres of competence and powers' and 'prioritizes functions'. ${ }^{5}$

Federal offices enjoy considerable power in making proposals during the pre-parliamentary phase. They are certainly subordinated hierarchically to the head of the department, as well as potentially subject to a Federal Council veto as it decides about each stage of the process, most especially in starting the consultation process (Art. 5 Consultation Procedure Act). Though responsible for the organization of the project, they nevertheless have an impact on the integration of knowledge and the extent of consultation in the drafting of bills.

Compared with other offices, the Federal Office of Justice enjoys important prerogatives, which has earned it the label of being the 'juridical conscience of the administration' (Mader 2006: 3). It guarantees control over the quality of draft laws, carries out legal assessments, and enacts an important part of the directives and formal legalistic guidelines. It also provides training for federal law clerks. This office has, in effect, designed and implemented a complete training concept—something found rarely even among Swiss university law faculties.

Ultimately, while it is formally a power of the Federal Council, it is the federal offices and even the general secretariats which exercise power over the pre-parliamentary process (Mader 2006: 7). This means a strengthening of public administration relative to the executive, so much so that some describe the federal administration as 'the fourth power' in the state (Häfelin et al. 2016: n. 1698). Of the relevant offices, the Federal Office

\footnotetext{
${ }^{5}$ Michel Crozier, 'Bureaucratie' in Encyclopædia Universalis. http://www.universalis.fr/ encyclopedie/bureaucratie/ (consulted on August 25, 2017).
} 
of Justice enjoys a particularly powerful position, a situation not without its problems. Indeed, the control of the preventive control of compliance with the law by an office raises questions of independence. Author of numerous bills-20\%, the office also happens to be the relevant office for the subject matter as well as the locus of preventive control, which could lead to conflicts of interest. It is therefore not surprising that, in response to a postulate, the Federal Council issued a report in which it declared itself satisfied with the status quo, while also advocating some modest optimization measures. It is thus perhaps not surprising that the Federal Council also opposes judicial review: if introduced, it could guarantee oversight by an organ of the state which would be independent of the government and parliament (Federal Council 2010).

\section{REFERENCES}

Auer, A., Malinverni, G., \& Hottelier, M. (2013). Droit constitutionnel (Vol. I). Berne: Staempfli.

Christe, J., Gava, R., \& Varone, F. (2016). Consultations et groupes d'intérêt: un aperçu quantitatif. LeGes, 2, 211-224.

Federal Council. (1970). Directives du Conseil fédéral du 6 mai 1970 concernant la procédure préliminaire en matière de législation. Fewille Fédérale I, 1002-1010.

Federal Council. (2004). Message du Conseil fédéral du 21 janvier 2004 relatif à la loi fédérale sur la procédure de consultation. Fenille Fédérale I, 485-512.

Federal Council. (2010). Rapport du Conseil fédéral du 5 mars 2010 sur le renforcement du contrôle préventif de la conformité au droit. Fenille Fédérale, 1989-2066.

Federal Council. (2011). Rapport du Conseil fédéral du 9 décembre 2011 sur l'évaluation de la loi fédérale sur la protection des données. Fenille Fédérale, 255-272.

Federal Council. (2017). Message du Conseil fédéral du 15 septembre 2017 concernant la loi fédérale sur la révision totale de la loi fédérale sur la protection des données et sur la modification d'autres lois fédérales. Fenille Fédérale, 6565-6802.

Federal Department of Economic Affairs, Education and Research. (2013). Analyse d'impact de la réglementation. Bern: Swiss Confederation.

Federal Office of Justice. (2007). Guide de législation, Guide pour l'élaboration de la législation fédérale. Bern: Swiss Confederation.

Federal Office of Justice. (2014). Esquisse d'acte normatif relative à la révision de la loi sur la protection des données. Rapport du 29 octobre 2014 du groupe d'accompagnement Révision LPD. Bern: Swiss Confederation. 
Federal Office of Justice. (2017). Avant-projet de loi fédérale sur la révision totale de la loi sur la protection des données et sur la modification d'autres lois fédérales. Synthèse des résultats de la procédure de consultation. Bern: Swiss Confederation. Flückiger, A. (2008). Qu'est-ce que “mieux légiférer”?: enjeux et instrumentalisation de la notion de qualité législative. In A. Flückiger \& C. Guy-Ecabert (Eds.), Guider les parlements et les gouvernements pour mieux légiférer: le rôle des guides de légistique (pp. 11-32). Genève: Schulthess.

Flückiger, A., \& Guy-Ecabert, C. (2008). Guider les parlements et les gouvernements pour mieux légiférer. Le rôle des guides de légistique. Zurich: Schulthess.

Flückiger, A., \& Guy-Ecabert, C. (2015). La bonne loi ou le paradis perdu? LeGes, $1,21-45$.

Grisel, A. (1984). Traité de droit administratif, I. Neuchâtel: Ides et Calendes.

Häfelin, U., et al. (2016). Schweizerisches Bundesstaatsrecht. Zurich: Schulthess.

Jochum, M., \& Ledermann, S. (2009). La démarche légistique entre théorie et pratique. LeGes, 1, 87-103.

Keller, M. (1997). Fragen des Vernehmlassungsverfahrens / Quelques interrogations sur la procédure de consultation. LeGes, 2, 11-15.

Latour, B. (2002). La fabrique du droit. Une ethnographie du Conseil d'État. Paris: La Découverte.

Mader, L. (2001). Bundesrat und Bundesverwaltung. In D. Thürer, J.-F. Aubert, \& J. P. Müller (Eds.), Verfassungsrecht der Schweiz (pp. 1047-1069). Zürich: Schulthess.

Mader, L. (2006). Das Bundesamt für Justiz: eine Dienerin vieler Herren? In R. Reusser \& B. Schindler (Eds.), L'atelier du droit. Mélanges en l'honneur de Heinrich Koller à l'occasion de son $65^{\complement}$ anniversaire (pp. 3-10). Basel: Helbing \& Lichtenhahn.

Müller, G., \& Uhlmann, F. (2013). Elemente einer Rechtsetzungslehre. Zurich: Schulthess.

Papadopoulos, I. (1997). La consultation: un outil de gouvernabilité? Fonctions et dysfonctionnements de la phase préparlementaire. LeGes, 2, 241-260.

PWC. (2016). Regulierungsfolgenabschätzung (RFA) zur Revision des eidg. Datenschutzgesetzes (DSG). Bern: PWC.

Sciarini, P. (2011). Les effets de la consultation sur les processus de décision au niveau fédéral. LeGes, 2, 191-204.

Sciarini, P. (2015). Introduction. In P. Sciarini, M. Fischer, \& D. Traber (Eds.), Political decision-making in Switzerland: The consensus model under pressure (challenges to democracy in the 21st century) (pp. 1-23). Basingstoke/New York: Palgrave Macmillan.

Vatter, B. (2011). Evaluation des Bundesgesetzes über den Datenschutz. Institut für Europarecht (Universität Freiburg), Schlussbericht. 
Open Access This chapter is licensed under the terms of the Creative Commons Attribution 4.0 International License (http://creativecommons.org/licenses/ by $/ 4.0 /)$, which permits use, sharing, adaptation, distribution and reproduction in any medium or format, as long as you give appropriate credit to the original author(s) and the source, provide a link to the Creative Commons license and indicate if changes were made.

The images or other third party material in this chapter are included in the chapter's Creative Commons license, unless indicated otherwise in a credit line to the material. If material is not included in the chapter's Creative Commons license and your intended use is not permitted by statutory regulation or exceeds the permitted use, you will need to obtain permission directly from the copyright holder.

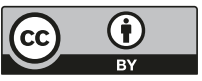

